\title{
Truth and freedom as the axiological foundations of practicing science at the Lvov-Warsaw School
}

\author{
Joanna Zegzuła-Nowak \\ Dttps://orcid.org/0000-0003-4280-849X
}

\begin{abstract}
The contribution is discussed of the Lvov-Warsaw School (LWS) in determining the axiological dimension of science. By promoting philosophical culture and solid axiological foundations, the School members aspired to imbue the spirit of patriotism and a sense of national community in society. They believed that if science is to serve humanity, it should not develop in an infinite and recalcitrant way. Apart from defining substantive and methodological directives, the LWS scholars regarded it important to draw up axiological frameworks of scientific studies to define their proper tasks and protect them against depreciating factors. Science, in their view, should promote and develop values. As they saw it, science based on clearly defined axiological foundations should not only seek to improve man's living, but also develop his inner life. Hence, the scholar's mission should adhere to set values, in particular truth and freedom, imbuing scientific work with the status of crucial and at the same time autonomous field of human activity.
\end{abstract}

Keywords: axiological dimension of science, Lvov-Warsaw School, truth and freedom in science

JOANNA ZEGZUŁA-NOWAK, PhD in philosophy, adjunct, Institute of Philosophy of University of Zielona Góra; address for correspondence: al. Wojska Polskiego 71A, 65-762 Zielona Góra, Poland; e-mail: J.Zegzula-Nowak@ifil.uz.zgora.pl 
Each field of reality requires the use of appropriate means and tools of influence: hence the social and psychological forms of "axiological emptiness" require social and psychological methods of interaction, aimed at filling it with live content.

Halina Promieńska, Trwanie i zmiana wartości moralnych

\section{The problem of axiological dimension of science}

Science is a sphere of activity that is a manifestation of human uniqueness and creative power in the world. It is also a response to the eternal cognitive desires of humanity, the pursuit of reliable and indisputable knowledge about the world. As modern scientists emphasize: "The ultimate goal of science, although perhaps impossible to reach, is to build a »theory of everything « that would unite the achievements of individual researchers and crown the cognitive effort of generations of scientists". There is, therefore, no doubt that its achievements, not only the constantly accumulated knowledge about the world and man, discovered facts, inventions, but also the directives setting the framework for scientific work, are the result of creative activity and mutual inspiration for many generations of scholars. Each generation of scientists provides important suggestions and often warnings to its successors.

Therefore, the progress of science is also a development of knowledge about ourselves. Its fortunes show that scientific activity is an area in which diverse, even often antagonistic, aspirations, inclinations and human interests constantly intersect. On the one hand, scholars desire to satisfy the cognitive ambitions that have been continually accompanying humanity for centuries. They want to know and understand the world around us, striving for truth and an objective approach to reality as well as exploring its secrets. Practicing science is also for them an area of self-creation, giving an opportunity to express their passions and satisfy their individual ambitions. Through their work, people of science strive to express their intellectual potential and realize their creative visions, transfer their full skills

1 Adam Świeżyński, "Doświadczenie aksjologiczne w poznaniu naukowym," in Oblicza doświadczenia aksjologicznego. Studia i rozprawy, eds. Piotr Duchliński, Grzegorz Hołub (Kraków: WAM, 2011), 446. 
and knowledge, implement ideas, and furthermore, also gain recognition and respect, not only from the scientific collective but also from the general public. On the other hand, science, as a sphere that allows us to transform the reality that surrounds us, aims to improve the conditions of human life (ensuring humanity's security, prosperity, happiness). Therefore, it plays an extremely important role in the society, involving not only the multiplication of human potential but also great responsibility. The development of science cannot take place in an unrestricted and uncontrolled manner. Hence, in the history of mankind a question arose about permanent standards specifying what scientists should be guided by in their scientific work and what activities and goals they should avoid. Thus, it turned out that science is an activity saturated with values. However, they are not and cannot be accidentally selected. The values present in science are the values reaching for the sources and foundations of our humanity.

Therefore, science requires setting its axiological frameworks. Only then can it constitute an adequate manifestation of the specificity of human activity in the world, showing its fullness, causative power and optima of possibilities.

Hence, for many decades, many native scientists, methodologists and philosophers have set themselves the goal of formulating leading and universal values, directives and postulates that would set legitimate and fair goals for science and allow it to be protected against depreciating factors.

These issues gained particular significance in the 20th century, in which echoes of past partitions resounded, and the experience of two world wars and the functioning of totalitarian systems showed that scientific progress should never go hand in hand with wicked actions and aspirations that violate the foundations of humanity i.e. dignity, freedom, health and human life. At that time, one of the most important changes regarding the vision of practicing science began, namely: "the transition from the concept of value-free science to the concept of value-saturated science". ${ }^{2}$ The thesis stating that human cognitive activity has also its axiological dimension has been increasingly emphasized. The value of science cannot be manifested only in its usefulness for finding means of efficient action but also in the very nature of its purpose, which should be good and fair. ${ }^{3}$ Therefore, it has been more and more boldly postulated that scientists must always keep in mind that both their activity and the results of their research

\footnotetext{
${ }^{2}$ Agnieszka Lekka-Kowalik, Odkrywanie aksjologicznego wymiaru nauki (Lublin: KUL, 2008), 5.

${ }^{3}$ Ibidem, 338.
} 
should have specific axiological properties. At that time Polish society began to be aware that it was science which significantly helped the national culture to survive the darkness of the partitions, times of war turmoil, as well as ideological enslavement and repression. When Polish sovereignty was threatened, it was the creative activity of outstanding people of science that proved to be the way to build interpersonal relationships and hold the society full of divisions together. That is why many native scientists have repeatedly emphasized the importance of values that science stores and passes to next generations of scientists.

Among them, activity of philosophers representing one of the most influential intellectual formations of the 20th century deserves a special attention, namely the Lvov-Warsaw School, i.e. Kazimierz Twardowski, Tadeusz Kotarbiński, Kazimierz Ajdukiewicz, Tadeusz Czeżowski, Stanisław Ossowski, Maria Ossowska and Mieczysław Wallis. The history of this intellectual formation shows that its representatives, practicing philosophy, were convinced that their scientific vocation was not only development of human knowledge, but also, and perhaps above all, building a sense of intellectual identity, national community, unity and solidarity among compatriots. This phenomenon was not accidental. Through subsequent generations of the school its representatives were aware that philosophers, as lovers of wisdom, have special universal responsibility for determining the limits of human cognitive activity, enabling scientists to practice science in the spirit of service for humanity. Therefore, their contribution to the development of Polish science and culture deserves, therefore, permanent recognition and dissemination.

\section{On axiological foundations of practicing science at the Lvov-Warsaw School}

Thus, scholars from the Lvov-Warsaw School treated practicing science as a kind of social mission. Their approach to scientific work shows their constant conviction, that science, despite constantly changing socio-historical conditions, can be a permanent factor of social transformation, development, progress, uniting the nation and establishing interpersonal relationships, even in a reality full of divisions and mutual antagonisms. So, since the dawn of the school's history, through its subsequent generations, there was a vivid conviction in it, that 
respecting certain solid axiological foundations should also correspond to the challenges of the changing historical reality and current socio-political conditions.

The Lvov-Warsaw school was born in a specific geopolitical situation for the Polish nation. Its beginnings date back to the political partitions. In this particular historical reality, Polish society struggled with many hardships and repression in everyday life. Native culture and science were also at risk.

Restrictions and repressions undertaken by the partitioners, various barriers posed to the development of Polish national culture also violated science, in particular the Polish humanities, in which the aspirations and desires of Polish society were so clearly reflected. And although objective conditions severely limited the possibilities of developing Polish humanities in a country divided into three partitions, they did not manage to suppress it. ${ }^{4}$

When in 1895 Twardowski arrived in Lvov, he was found in the Austrian partition, in which the situation allowed his scientific, didactic and social aspirations to develop. In Galicia, the situation of Polish people was the least oppressive and at the same time most conducive to the development of national autonomy in science. First of all, it was there that the opportunity to study in the native language appeared. As historians indicate: “in connection with Galicia's obtaining of autonomy, there was a polonization of universities in Krakow and Lvov". ${ }^{5}$ Therefore, the University of Lvov has become one of the dynamic centers for the development of Polish science, especially the humanities and social sciences. Importantly, his activity was inspired by the conviction that science can play the role of an important catalyst for social transformation, primarily due to the adoption of its new paradigm, which was associated not only with the general professionalization of the humanities, but also with the process of its scientification. Twardowski in his scienific program was also inspired by the utilitarian concept of science underlying the reform of German universities. Its fundamental premise was the thesis that: "the essential power of the nation lies in the field of the spirit, and the university's task is to educate the intellectual elite of the country, which is to be the expression of the spirit of the nation [...]. In

${ }^{4}$ Historia nauki polskiej, t. IV. 1863-1918, cz. III, ed. Zofia Skubała-Tokarska (Wrocław, Warszawa, Kraków, Gdańsk, Łódź: Zakład Narodowy im. Ossolińskich - Wydawnictwo Polskiej Akademii Nauk, 1987), 465.

${ }^{5}$ Ibidem, 468. 
educating this intellectual elite, philosophy was to take the lead". ${ }^{6}$ What was significant, he found himself in a scientific academic center, where philosophy as an academic discipline had been neglected, there was neither a philosophical seminar nor, more importantly, any tradition of serious philosophical studies. Thus, the scientist had to start work from scratch. At the University of Jan Kazimierz, Twardowski gained an opportunity to build and develop philosophy, both - its methodological and academic framework. Therefore, the scientist had the task not only to formally organize philosophical academic studies, but also, and perhaps above all, to develop a new way of practicing philosophy. Twardowski's main aspiration was to raise the philosophy to the rank of science. In this way he separated philosophy from worldview, also negating metaphysical issues from its considerations. He also broke with the model of practicing philosophy aiming at its systemic approach, focusing on specific issues and research problems. He was motivated by the desire to initiate a Polish philosophy that would meet the requirements of scientific criticism. The philosopher wanted to develop philosophy in Poland, teaching how to practice it in reliable way. $\mathrm{He}$ proclaimed that philosophy as a science must use only methods that meet the criteria of science. Hence, the programmatic mindset of its school was the attitude, which in time K. Ajdukiewicz described as logical anti-irrationalism ${ }^{7}$. Its essence was to: "cultivate philosophy according to the same criteria of rigor that the leading methodological sciences adhere to and [...] apply in the philosophy the conceptual apparatus of symbolic logic" ${ }^{8}$ This attitude was first and foremost an expression of intellectual distance to any irrational thinking. With the development of the school, it has also gained social application. As Peter Simons emphasizes: "During the flourishing of the School's activities, totalitarianism: pseudoscientific Marxism or fascism [...] was the main and direct threat to the entire society, and also to rational, critically thinking philosophers". ${ }^{9}$ Hence, the postulates resulting from the attitude of logical anti-irrationalism - scientific

\footnotetext{
${ }^{6}$ Ibidem, 27.

${ }^{7}$ Ryszard Jadczak, Powstanie filozofii analitycznej w Polsce. Noty Bibliograficzne (Torun: Adam Marszałek, 1995), 399-408.

8 Witold Marciszewski, "Kwestia unaukowienia racjonalizmu przez logikę matematyczną a logistyczny antyirracjonalizm Szkoły Lwowsko-Warszawskiej," in Fenomen Szkoly LwowskoWarszawskiej, eds. Anna Brożek, Alicja Chylińska (Lublin: Academicon, 2016), 75.

${ }^{9}$ Peter Simons, "Filozofia logiczna, antyirracjonalizm i równość płci. Trzy atuty Oświecenia lwowsko-warszawskiego," in Fenomen Szkoły Lwowsko-Warszawskiej, 29.
} 
criticism, distrust of all forms of speculative thinking, negation of views having no sufficient justification (based on logical argumentation) as well as ideological and worldview positions, turned out to be an important weapon in the fight for intellectual independence. Therefore, Twardowski introduced to philosophical research a style of work based on strict research methods, and, more importantly, permanent axiological foundations, which have become the intellectual binder of all its generations. With time, they also began to constitute a peculiar phenomenon of the then Polish philosophy.

In his persistent, long-term work, Twardowski, by cultivating lasting scientific demands, as well as the intellectual and academic development of his students, initiated a great reform of native philosophy, making a significant contribution to Polish culture and science. ${ }^{10}$ His students after World War I dispersed all over Poland, occupying the departments of newly established university centers - in Warsaw, Vilnius and Poznań. In the interwar period, they already occupied most of the departments of philosophy of the country, also affecting other disciplines, e.g. literature, musicology and classical philology. In this way, Twardowski and his first students aimed not only at strengthening the sense of bond among compatriots in the post-partition reality, but also at the intellectual renewal of the nation after its political revival. As pointed out R. Ingarden, the main scientific and pedagogical goal of Twardowski was: "creating a new philosophical atmosphere, bringing up new young philosophers [...] for the great benefit of Polish philosophical culture". ${ }^{11}$ This activity even took precedence over his research and creative work.

This work would not have been possible without recognition for the conviction that the role of a scholar should not only be the study of theoretical scientific problems, but also the recognition of current socially important problems and an attempt to search for ways to solve them. This attitude became an important determinant of all the philosophical activity of the Kazimierz Twardowski school. As T. Czeżowski wrote:

${ }^{10}$ Jacek Jadacki, "The Lvov-Warsaw School and Austro-German Philosophers. Two Cases," in: The Significance of the Lvov-Warsaw School in the European Culture, ed. Anna Brożek (Wien: Springer, 2017), 78.

${ }^{11}$ Roman Ingarden, “Główne kierunki polskiej filozofii,” Studia Filozoficzne 1973, no. 1: 7. 
Today we owe the unity of Polish philosophy, despite the variety of currents that bother it. [...] Twardowski's philosophy shows a certain common feature with the Sniadecki philosophy, with all our romantic philosophy, with the later aspirations of Polish positivists. This common feature is the relationship between philosophy and life, considered by many to be a characteristic feature of Polish philosophical thought in general. ${ }^{12}$

Importantly, for many reasons their pioneering and also timeless approach to the role and social status of science, can be a kind of intellectual signpost, also for contemporary scholars, showing strongly that not every way of practicing science and not every effect of it serves people and is worthy of its existence.

These 20th century philosophers, bearing in mind not only the history of humanity, but also the times in which they lived, left to next generations a directive stating that the achievements of science should never be paid for with suffering, enslavement, human health and life, even in the name of the greatest progress and development of knowledge. This is because it affects both the ethos of scholars, as well as the very vision of science as cognitive activity, which should be aimed not only at striving to understand the world and human place in it, but also to provide society with decent living conditions. What is more, in the science with strong and clearly defined axiological foundations, they saw not only the way to improve human life, but also the promotion and development of culture and internal human development. Hence, Kazimierz Twardowski, believing in such momentous power of science, preached the cult of science also on the basis of philosophy. ${ }^{13}$ He also inculcated this view in his students.

He postulated practicing scientific philosophy, that is one which applies scientific methods in its research, and not the one based on personal convictions, even if they seemed the most irresistible, setting research goals within the world available to

${ }^{12}$ Tadeusz Czeżowski, "Kazimierz Twardowski jako nauczyciel," in: Kazimierz Twardowski. Nauczyciel - Uczony - Obywatel (Lwów: PTF, 1938), 22.

${ }^{13}$ Jan Skoczyński, Jan Woleński, Historia filozofii polskiej (Kraków: WAM, 2010), 409; Jan Woleński, Filozoficzna szkoła lwowsko-warszawska (Warszawa: PWN, 1985), 36; Ryszard Jadczak, Powstanie filozofii analitycznej w Polsce, 31-32; Elżbieta Paczkowska-Łagowska, Psychika i poznanie. Epistemologia Kazimierza Twardowskiego (Warszawa: PWN, 1980), 11; Joanna Zegzuła-Nowak, Polemiki filozoficzne Henryka Elzenberga ze szkołą lwowsko-warszawską (Kraków: Scriptum, 2017), 54-57. 
scientific research, and not these which would solve the most distant ideological issues". ${ }^{14}$

He defined science itself as a peculiar product of the human spirit, aiming at "exploring the essence and internal relationships of things" ${ }^{15} \mathrm{He}$ also claimed that it can vave both - cognitive and practical value. This position was also approved by other School representatives. For example, Mieczysław Wallis, one of Tadeusz Kotarbiński's closest students, argued that the peculiarity of science is mainly manifested in the vastness of its practical applications. They constantly pass the wildest expectations of people, irreversibly transforming their life, sharpening their senses and making their bodies powerful. However, he believed, the same as the founder of the School, that there is more impact of science on human life. Its influence manifests itself most fully in the sphere of the human spirit and inner experience implied by it. As he wrote further on: "But you can also think that even this enormous practical value of [science ${ }^{16}$ is insignificant, is of a lower value and may be neglected in the face of the value of science as an inexhaustible source of cognitive and aesthetic joy. What do the benefits and liberation from suffering mean in the face of joy"17? The scholar argued that something extremely majestic appears in science, associated with the specificity of the creative process that accompanies it, which is particularly attributable to human nature. It is because of it that human-specific, unique axiological sensations become present. They create an area of special contentment, delight, emotion, intellectual elation and happiness, allowing man to go beyond ordinary routine and hardships of life. The scholar wrote about it in his typescripts as follows:

The joy of creating - arranging, building, shaping: from the joy of a child who managed to build »a real house« from blocks, or a potter kneading a clay pitcher, to

${ }^{14}$ Tadeusz Czeżowski, "Wkład Kazimierza Twardowskiego do teorii nauki," Ruch Filozoficzny 19, no. 1-2 (1959): 5 .

${ }^{15}$ Kazimierz Twardowski, Podstawy wiedzy ludzkiej: Odczyt wygłoszony w Bibliotece Polskiej ${ }_{W}$ Wiedniu: http://rcin.org.pl/dlibra/aresults?action=SearchAction\&QI=E373A6B0B85B 7B22732F18789 DF6B156-1 (access: 16.09.2019); Ryszard Jadczak, "Kazimierz Twardowski o nauce i jej funkcjach,” Zagadnienia Naukoznawstwa 4, no. 104 (1990): 624.

${ }^{16}$ Personal note.

${ }^{17}$ Mieczysław Wallis, Materiały Archiwalne (Warszawa: Archiwum Połączonych Bibliotek WFiS UW, IFiS PAN oraz PTF), folder Rps 21: 131. 
the joy of an educator, creating young souls, an artist composing an image, poem, melody, a scholar, formulating a new theory, is one of the greatest and most moving joy. A sense of one's own power that brings new entities out of nothingness; satisfaction with the perfection of a new creation; pride in having enriched the world; happiness in making other people happy: all of it resounds in the joy of creation. $^{18}$

Therefore, in addition to typically utilitarian benefits, science is a source of particular sensations that can only be shared by human being. They also constitute one of the forms of expression of typical human beings in their axiology-oriented activity. Owing to science man becomes both a great explorer, creator and builder of the surrounding reality and also enters the world of her/his inner life and creations.

Furthermore, science can also be a form of dialogue, openness to other people, building relationships despite the existence of social and political, ideological or religious divisions. It also teaches that it is worth putting the general good above our own.

Hence, the philosophers from the Lvov-Warsaw School were convinced that the creative and discovery activity gains its fullness only by satisfying values, and not only of cognitive nature. The main idea of research, especially in the field of philosophy, is to deepen the knowledge about the world and to fulfill certain moral obligations. As Izydora Dąmbska wrote about the program assumptions of her master: "According to Twardowski, practicing philosophy is not only solving certain theoretical problems. This is also a way of deepening and improving of one's morality, a way of gaining true life wisdom, a way to internal independence and self-control". ${ }^{19}$ Thus, there is a commitment of scholars to implement certain values, which are primarily headed by truth and freedom. As Kazimierz Twardowski preached in his programme and was followed by other leading representatives of the School: "A philosopher is [...] a man who aims at objective truth through scientific work in the field of philosophical sciences, who, in his/her pursuit, is free from prejudices of everyday life and from those imposed by the prevailing social and political views that prevail over tendencies that could

\footnotetext{
${ }^{18}$ Ibidem, folder Rps 19, vol. 3-5: 178.

${ }^{19}$ Izydora Dąmbska, “Czterdzieści lat filozofii we Lwowie 1898-1938," Przegląd Filozoficzny 44, z. 1-3 (1948): 15.
} 
confuse scientific impartiality" ${ }^{20}$ Therefore, philosophers from Twardowski's School believed that truth and freedom in science are closely related and mutually conditioning each other, giving a scientific activity a status of momentous and autonomous sphere of human activity. As A. Dylus points out: "Freedom and truth were almost slogan norms of their science ethics. [...] The freedom of science is a condition for the reliable pursuit of the truth, but in turn, the justification for uncompromising demand for this freedom is the conviction that truth is the unequivocal good of humanity". ${ }^{21}$

Therefore, when civil freedom as well as creative freedom and scientific truth were threatened, philosophers from the Lvov-Warsaw School defended them with particular determination, both in their creative work and social activity. It was particularly evident during the period of the intensified Marxist offensive, both in social and political life, as well as in science and education itself. The political situation of Poland after 1945 had a huge impact on the fate of Polish science. Its leading researchers also assume that this was the end of school understood as a close intellectual community. ${ }^{22}$ At that time, science was often subject to restrictive or even depreciating regulations. Its results were falsified and concealed and scientific truth was sacrificed in the name of ideological goals. Many of philosophers of that time, conducting both scientific and didactic activity, fell victims of the repressions - their statements were blocked and censored, their works were prevented from being published, and they were removed from academic activities. Many scholars from the Lvov-Warsaw School also shared this destiny, hence many of them decided to emigrate. ${ }^{23}$ For those representatives of the school who, despite the hardships of post-war Polish reality, did not cease their scientific activity (primarily Kotarbiński, Ajdukiewicz and

${ }^{20}$ Tadeusz Czeżowski, “Kazimierz Twardowski jako nauczyciel,” 9.

${ }^{21}$ Aniela Dylus, Problematyka etyki nauki u przedstawicieli szkoły lwowsko-warszawskiej (Warszawa: Akademia Teologii Katolickiej, 1987), 41 and 59.

${ }^{22}$ Jan Woleński, “Jak mówić o historii filozofii analitycznej?”, in Fenomen Szkoły LwowskoWarszawskiej; 48.

${ }^{23}$ The history of the Marxist offensive against scholars from the Lvov-Warsaw School is presented, among others the following publications: Ryszard Jadczak, "Z dziejów spotkania szkoły lwowskowarszawskiej z marksizmem," Edukacja Filozoficzna 1991, vol. 11: 99-107; Radosław Kuliniak, Mariusz Pandura, Łukasz Ratajczak, Filozofia po ciemnej stronie mocy. Krucjaty marksistów i komunistów polskich przeciwko Lwowskiej Szkole Filozoficznej Kazimierza Twardowskiego. Część pierwsza: lata 1945-1951 (Kęty: Marek Derewiecki, 2018); Witold Mackiewicz, Polska filozofia powojenna (Warszawa: Witmark, 2001). 
Czeżowski) the issues of struggle for the axiological foundations of science, and thus the autonomy of its practice, became extremely important at that time.

However, their situation was not easy. At the First Congress of Polish Science (1951), Schaff openly recognized critics of the Lvov-Warsaw circle as one of the main tasks of Marxist philosophy. In the article Tasks of the Philosophical Front in the light of the resolutions of the First Congress of Polish Science, he wrote as follows: "The struggle of the two camps today is particularly vividly reflected in the field of philosophy [...]. The struggle of the proletariat against the bourgeoisie is also, among others, the struggle of proletarian philosophy against bourgeoisie, consistently materialist philosophy against idealistic philosophy". ${ }^{24}$ This situation was reflected in articles not only by Schaff, but also by H. Holland, B. Baczko, J. Chałasiński, T. Kronski and L. Kołakowski. In their statements, they formulated a number of allegations, which in fact constituted a form of ideological struggle and an expression of strong opposition to philosophers from the LvovWarsaw school, who were unwilling to adopt the worldview of Marxist philosophy. Importantly, this criticism was ussually deprived of substantive arguments and increasingly formulated in an aggressive language, full of invectives and epithets. Despite this, their scientific convictions and values have not changed or depreciated. In the vision of science satisfying the postulates of reliability and methodological accuracy as well as axiologically oriented, they saw an effective way of opposing or breaking ideological and political shackles, proudly facing, sometimes even only through cold reserve or tolerance, repression by post-war Marxists and communists, not succumbing to socialist realist influences. ${ }^{25}$ As scholars, they were aware of great social responsibility for their scientific work and the impact they have on the society. Therefore, they were even more aware that science should be protected against factors threatening its nature and goals, above all against its depreciation in the name of ideological and political service.

Considering the timeliness of the views of scholars from the Lvov-Warsaw School, it is therefore worth following the axiological path that they pointed out to the people of science - as defenders of the native mentality and culture, praises the value of truth and freedom.

\footnotetext{
${ }^{24}$ Jan Woleński, Filozoficzna szkoła lwowsko-warszawska, 306.

${ }^{25}$ Radosław Kuliniak, Mariusz Pandura, Łukasz Ratajczak, Filozofia po ciemnej stronie mocy, 7.
} 
Science in the service of objective truth

In the Lvov-Warsaw School, the most important goal of practicing science was undoubtedly the pursuit of truth. This goal was set above all others. Importantly, however, "the ideal was the objectivity of scientific cognition, but not at the cost of eliminating entire areas of knowledge from science (e.g. normative ethics). ${ }^{26}$ Truth was considered to have a dimension not only of cognitive but also of moral value. Practicing science in the service of objective truth allows not only to describe and explain the phenomena around us. The truth, as Twardowski argued: "can free humanity from a series of troubles, so serving the objective truth acquires an ethical meaning". ${ }^{27}$

This is the reason why this value was the basis of the School's ethics. As Włodzimierz Tyburski points out: "It was common among representatives of the Lvov-Warsaw School that realization of scientific truth becomes the highest value for a scientist" ${ }^{28}$ It was recognized that the pursuit of it results from the natural human inclination - a desire to know and understand the reality that surrounds us as it is and eventually determine our place in this ordered unity. Only in the environment understandable to us, we will be able to feel safe and strive to achieve happiness and our human fulfillment. What is more, Mieczysław Wallis claimed that, thanks to a high level of intellectual creativity, man discovers his fullness, authenticity, specificity, internal integrity and honesty. Therefore, in science there is no place for conformism, falsehood, illusion, cheating, even in the name of the best understood interest of the individual or general public. ${ }^{29} \mathrm{He}$ wrote about it as follows: "I think that it is in the spirit of reliable science that we strive for the clearest realization of its character, foundations and possibilities. Science is not a religion. It does not require us to

\section{${ }^{26}$ Dylus, 5.}

${ }^{27}$ Ibidem, 59-60; Kazimierz Twardowski, O dostojeństwie Uniwersytetu (Poznań: Uniwersytet Poznański, 1933), 11.

${ }^{28}$ Włodzimierz Tyburski, "Etos uczonego w Szkole Lwowsko-Warszawskiej," in Polska filozofia analityczna. W kręgu szkoły lwowsko-warszawskiej, eds. Włodzimierz Tyburski, Ryszard Wiśniewski (Toruń: UMK, 1999), 130-131.

${ }^{29}$ Wallis, folder Rps 19, vol. 3-5: 174-175. 
belive in it. It wants us to approach it also with the harsh and critical attitude with which it approaches the subjects of its research". ${ }^{30}$

Philosophers of this School, following their master, recognized the truth as an autotelic value, worth realizing not only for utilitarian purposes but also for itself. Kazimierz Twardowski wrote about the essence of scientific work a vocation to build "a temple of knowledge is great happiness. For people can nowhere find more lasting and purer satisfaction than in an unselfish search for scientific truth". ${ }^{31}$ Therefore, the role of those who practice philosophy is to show other scholars how to approach the truth. As he wrote further: "By making the truth itself a subject of its research, lighting up the paths leading to it, creating the theory of scientific knowledge, philosophy becomes the ally and guide of all who strive for truth in any field of human inquiry". ${ }^{32}$

It is worth to notice, that discovering the truth itself also combines with great responsibility. The practical application of scientific research results may have various consequences for human existence, which scholars should be aware of. At the Lvov-Warsaw school, this issue slightly differentiated the attitudes of individual representatives. Twardowski presented a strongly affirmative position, not critical enough, because he did not see possible threats resulting from the use of scientific and technical knowledge. A similar position was also represented by his first students, J. Łukasiewicz and W. Witwicki. As Aniela Dylus points out that, Twardowski emphasizing (in one of his articles) the specificity and importance of scientific and technical knowledge, completely ignored the possibility of using it against man. ${ }^{33}$ The explanation of this position is probably the fact, that it was formulated before the outbreak of World War II, i.e. in the period preceding the times that exposed with the force, that science can also be successfully used for purposes harming human dignity, existence and wellfare. However, Twardowski wasn't an idolatrous apostate of science. He was aware of the many threats ahead of it. First of all, he warned other scholars against succumbing to the temptation of personal beliefs and predilections in the field of scientific and didactic work, which could harm the value of truth and the

\footnotetext{
${ }^{30}$ Wallis, folder Rps 21: 89.

${ }^{31}$ Twardowski, $O$ dostojeństwie Uniwersytetu, 18.

${ }^{32}$ Ibidem.

${ }^{33}$ Kazimierz Twardowski, "Dlaczego wiedza jest potęgą," Ruch Filozoficzny 1976, no. 12: 28; Dylus, 148.
} 
principles implied by it. He emphasized that philosophy lecturers were particularly vulnerable to it. Thus, they should be aware of their intellectual contribution and work in the spirit of reliability, credibility and validity of the statements made. He wrote:

Those who teach philosophy can easily be tempted to proclaim views inaccessible to scientific justification, they can easily become apostles of certain world views. I am convinced that the university lectern is not the right place for this kind of apostolate; students should only hear the words for which the teacher can take full scientific responsibility. ${ }^{34}$

In turn, Tadeusz Kotarbiński and Maria Ossowska noticed the definitely negative consequences of the application of scientific knowledge. On the one hand, the author of "Meditation on a decent life" had similar beliefs as his master, emphasizing that philosophical activity determining the paths which ought to be followed by scholars, should always have the goal of striving to proclaim the truth about the world that it is honestly believed. Nothing can justify a lie, there is no "right" motive or purpose for it. There is no conformity in this respect. The scholar argued as follows:

"The philosopher is ready to make a painful sacrifice for an effective cooperation.
However, he does not want to and cannot and does not want to be able to give up
something which appears to him as truth. He wishes himself and other philosophers
would always and everywhere be allowed to preach the truth and speak in a word
to defend it". ${ }^{55}$

But on the other hand, scholars should be also aware, that science can have destructive power. Especially in the hands of immature people who antagonize each other. Then it can deepen the crisis of interpersonal relations, providing destructive tools for fighting that, can result in unpredictable threats and disasters. $^{36}$

${ }^{34}$ Kazimierz Twardowski, "O dostojeństwie Uniwersytetu. Wprowadzenie i przygotowanie do druku wykładu Twardowskiego," ed. Ryszard Jadczak, Zagadnienia Naukoznawstwa26, z. 3 (1990): 378.

${ }^{35}$ Tadeusz Kotarbiński, “Upragnione fantazmaty,” in: Tadeusz Kotarbiński, Pisma etyczne (Wrocław, Warszawa, Kraków, Gdańsk, Łódź: Zakład Narodowy im. Ossolińskich, 1987), 430.

${ }^{36}$ Tadeusz Kotarbiński, “Kilka słów o walorach nauki," in Tadeusz Kotarbiński, Wybór pism, t. II. Myśli o myśleniu (Warszawa: PWN, 1958), 339. 
His student, Maria Ossowska, although noticed the beneficial influence of modern science on everyday functioning of a human being, she expressed numerous fears about its application in various spheres of life. Her position was dictated, however, or perhaps above all, by reference to other socio-political conditions than those, that built the context of Twardowski's statement. In her conclusions, echoes of ,the age of crematoria, the age of extermination, the age of nuclear bombs" ${ }^{37}$ clearly resonated. The scholar was already aware, that the belief that scientific progress goes hand in hand with the moral progress of humanity turns out to be a groundless dream. The development of human knowledge is also progress in the sphere of activity enabling the use of increasingly more elaborated forms of enslavement of man by man. As an argument, she gave the example of drastic treatments for mental illness, which contemporary medicine ultimately abandoned. She also underlines that: "sophisticated methods of torturing prisoners are also the result of advances in knowledge". ${ }^{38}$ She pointed to many different threats that may arise as a result of incorrect application of science, which can be included in contemporary discussions in the field of bioethics. First of all, she warned against uncritical recognition of the development of eugenics and physics. Hence, she vividly pointed out, that people of science have a special duty to stigmatize scientific practices that threaten humanity. Isolation against these problems is a betrayal of the ethos of the man of science. She already appealed for this attitude in science in 1935, using the following words: "In the destructive powers of science applied to the war industry, a researcher should be better oriented than anyone else. He also has a special responsibility, and he has the duty to speak loudly about these matters" ${ }^{39}$

The voice of scholars on socially important matters also gains special significance in the activities of those who are responsible for education and shaping moral attitudes of the society, i.e. university teachers.

\footnotetext{
${ }^{37}$ Maria Ossowska, "Fizyka współczesna a postawy moralne," in Maria Ossowska, O człowieku, moralności i nauce. Miscellanea (Warszawa: PWN, 1983), 458.

${ }^{38}$ Maria Ossowska, "Moralność: postęp czy regres," in Maria Ossowska, O człowieku, moralności i nauce, 527.

${ }^{39}$ Maria Ossowska, "Konferencja w Oksfordzie w sprawie obrony wolności akademickiej," in: Maria Ossowska, O człowieku, moralności i nauce, 292.
} 
This belief was visible, among others in the intellectual attitude of Tadeusz Czeżowski, for whom the essence of academic work was not only the possibility, but even the imperativeness of proclaiming the truth and maintaining objectivity.

He wrote: "An academic teacher has the right - not only the right but the obligation - to teach what he believes is true. [...] the professor is therefore to profess from the lectern what is his scientific conviction, regardless of political or religious censorship". ${ }^{40}$ Hence, the university teacher should remain cautious about joining the circle of ideological formations and actively implementing its assumptions. Incorporation: "the scholar in the ideological struggle was recognized by Czeżowski and other school representatives [...] as a threat to scientific objectivity, they also considered belonging to ideological organizations as a definitely inadvisable path for the scholar" ${ }^{41}$ Czeżowski emphasized that all ideological organizations constitute a threat to the "spirit of impartial criticism" on the basis of academic activity. ${ }^{42}$

The objective truth service so rigorously proclaimed at the Kazimierz Twardowski school was the object of many critical references, primarily after World War II, especially from polemists engaged in specific ideological and political currents. These polemics were conducted primarily under the guise of a lack of social involvement in attitudes of representatives of the Lvov-Warsaw school. Czeżowski's stand affirming objective truth as the foundation of the deontology of the profession of a researcher was the object of criticism, among others by Mark Fritzhand. In his polemic, this thinker instructed Czeżowski, that a scholar can't hide behind the cult of truth in science and avoid evoking ideological values, important from the point of view of social interest. He argued that the role of a scholar, as an educated and knowledgeable person, should be ideological advocacy of a trend considered as socially desirable, guaranteeing social progress and peace. M. Fritzhand proclaimed the following:

From the quoted by prof. Czeżowski passages, it appeared that there was a conflict between the scholar's obligation to seek truth and his social commitment. This

${ }^{40}$ Tadeusz Czeżowski, "Uniwersytet Nowoczesny. Przegląd zadań i zasad organizacyjnych,” in: Tożsamość uniwersytetu. Antologia tekstów profesorów Uniwersytetu Mikołaja Kopernika, ed. Włodzimierz Więcławski (Toruń: Oficyna Drukarska Wojewódzkiej Biblioteki Publicznej i Książnicy Miejskiej im. Mikołaja Kopernika w Toruniu, 1994), 19.

${ }^{41}$ Dylus, 143.

${ }^{42}$ Ibidem. 
doesn't seem to be a correctly formulated postulate: a scientist should be devoted solely to the ideal of truth. [...] As a man and citizen, he also has other duties and values; in addition to seeking the truth, he also has specific responsibilities for social and ideological involvement. ${ }^{43}$

The founder of the Lvov-Warsaw school himself also expressed the attitude of ideological and political independence in the field of science and education. As a citizen, he presented rather a political reserve attitude, strongly proclaiming that the school as a place promoting patriotic values should be free from ideological struggle and political influence. He preached with affection that: „[...] politics in the life of our society occupies such a great place that it squeezes itself into areas where it can only cause harm. We have been and are witnessing the fact that the school has become a weapon of political struggle". ${ }^{44}$ Hence, despite granting teachers the right to participate in public and political life no less than that of other citizens, he also pointed out that in performing their professional duties they should never advocate any political option and take part in political propaganda. He argued that:

Comparing the school with the election sounds like dissonance. [...] election with indispensable agitation and struggle, applying for the grace of the mighty or the crowd, with all this apparatus, sometimes having little to do with logic and ethics, should not even reach the walls of a school, which serves not the slogans of a given moment, not the interests of the parties, not the passing of time or transient purposes, but works to realize the ideals of the nation and humanity" 45 .

What's more, his axiological radicalism even meant that as a scholar and teacher he took a skeptical attitude towards phenomena that could arouse his civic recognition. For example, in one of his speeches, as a teacher, he expressed strong opposition to the boycott of the Russian school in the Kingdom. He proclaimed: "I don't feel competent or vocated to speak on whether this measure of fight is appropriate, $[. .$.$] the judgment [. .$.$] on the political appropriateness of a boycott$

\footnotetext{
${ }^{43}$ Marek Fritzhand, "Dyskusja nad referatami prof. dr. T. Czeżowskiego i dr. H. Jankowskiego," Etyka 1967, no. 2: 134.

${ }^{44}$ Kazimierz Twardowski, Mowy i rozprawy z okresu jego działalności w Towarzystwie Nauczycieli Szkół Wyższych, ed. Karol Zagajewski (Lwów: Towarzystwo Nauczycieli Szkół Wyższych, 1912), 10.

${ }^{45}$ Ibidem, 170.
} 
we must leave the future, and today we can only express a strong wish that this measure would prove effective and win a national school for the Polish people living under Russian occupation. [...] we cannot ignore the fact that from the position of the pedagogical mission the current state of affairs in the Kingdom is regrettable, because it brought political struggle to a field that should remain free from this struggle". ${ }^{46}$

However, this attitude didn't result total lack of socio-political commitment. Twardowski proclaimed that the teaching mission should be also carried out in the name of civic work: "Animated by the idea of such service [...], teachers are not limited to perform their duties, marked by the wording of the regulations, but they hurry wherever they are called by the social obligation, both at school like out of school". ${ }^{47}$

In the Lvov-Warsaw School, therefore, the service for truth was considered not only as an indispensable condition for acquiring and transmitting knowledge, but also as a value regulating social life. What is more, it was realized that fulfilling the truth and protecting it against an abusive use and distortions requires consideration of many important, even fundamental directives and values in the work of scientists. Thus, truth is a constitutive value for the scientist's ethos, determining a specific framework for all areas of his activity (research, teaching and education) - substantive, methodological and ethical ones. As one of LvovWarsaw School's researcher points out: “To create this value, a scholar should respect specific rules and principles" ${ }^{48}$ Therefore, truth also implies such valuable qualities as: honesty, sincerity, reliability, impartiality, criticism, competence, tolerance and justice. Representatives of the Lvov-Warsaw school often expressed their recognition in their social and civic attitudes. ${ }^{49}$ For example, as J. J. Jadacki points out, K. Ajdukiewicz was: "As a member of society - was concerned about his own dignity and universal freedom".${ }^{50} \mathrm{He}$ was also actively realizing the value of patriotism on the fronts of World War I and the Polish-Soviet war, and fighting the occupier for the spiritual survival of the nation by participating in secret

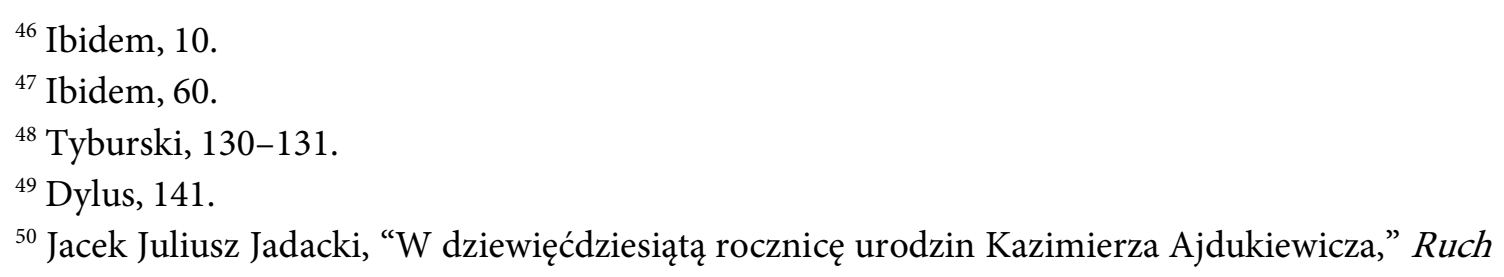
Filozoficzny 1981, no. 1: 6. 
teaching. Similar attitudes were taken by representatives of the second generation of the school, M. Wallis, and M. and S. Ossowskis. Wallis was a participant in the Polish-Bolshevik war, "for which the future scholar received the Medal of Independence". ${ }^{51}$ In 1939, he also participated in the defense of occupied Warsaw. At that time he was interned by the Germans and sent captive camps, first to Osterode, and next to Woldenberg, where he spent a total of 5 years. In dealing with other people, he guarded such values as: respect, kindness, modesty, sacrifice. As his student, Wanda Nowakowska recalls:

Professor Mieczysław Wallis was an extremely modest man, endowed with great personal culture, calmness, silence of deep weather, focused on really important matters. He radiated these qualities, shaping not only the way of being of his students, but creating a specific atmosphere of the Department [...], He was also extremely kind, always ready to give advice and help. ${ }^{52}$

In turn, M. Ossowska proved with her activity that a man of science, as an individual with momentous creative aspirations, also has important civic responsibilities and should actively engage in current, pressing problems raised in public life. Therefore, in the face of threats to freedom of speech, scientific truth and democratic freedoms, she has repeatedly participated in dissident activities. For example, in 1964, she signed the famous protest letter against censorship restrictions (so-called "Letter 34"). ${ }^{53}$ Whereas the essence of S. Ossowski's attitude, that satisfies the truth and the values related to, took T. Kotarbiński in the following words: "He was a knight of justice. He did not allow to corrupt the living idea of socialism, to make it a rigid tool of imperious decrees, to suppress utilitarian falsehood, to protect the rights of dependent people, to tell the truth to the eyes of those whom he depended on" ${ }^{54}$

${ }^{51}$ Wanda Nowakowska, Sylwetki łódzkich uczonych. Profesor Mieczysław Wallis (Łódź: Łódzkie Towarzystwo Naukowe, 2001), 8.

${ }^{52}$ Ibidem, 7.

${ }^{53}$ Jan Skoczyński, Jan Woleński, Historia filozofii polskiej, 540; Andrzej Friszke, Anatomia buntu. Kuroń. Modzelewski i komandosi (Kraków: Znak, 2010), 127.

${ }^{54}$ Tadeusz Kotarbiński, Myśli o ludziach i ludzkich sprawach (Wrocław, Warszawa, Kraków, Gdańsk: PAN 1986), 261. I present the problem of social and public involvement of the Ossowskis more broadly in: "Wzorzec człowieka nauki w założeniach programowych i postawach naukowych Marii i Stanisława Ossowskich," in W kreggu twórczości Marii Ossowskiej: analiza - inspiracje - alternatywy], 
Another precious value, without which the pursuit of the truth about the world becomes a fruitless misery or a wicked virtuosity of appearances was for the philosophers from Lvov-Warsaw school the freedom to practice science. Human cognitive activity cannot be restricted in any subjective way that is detrimental to the main aims of science, intended to serve all humanity.

\section{Freedom to practice science} as its principal axiological foundation

As Alina Dylus emphasizes: "Important values for all scholars from the LvovWarsaw School, headed by its founder, were: independence and freedom of science in general and the entity that practices it". ${ }^{55}$ And they were closely related to the value of truth. In the Lvov-Warsaw School, it was proclaimed that in order to discover the truth about the world, and implement the mechanisms governing it iin the service of humanity, scholars could not be enslaved in their actions (either by external influences or particular interests or the needs of the people who create it). Only people who are unrestricted in their pursuit of truth, will be able to accurately recognize it and unconditionally accept it ${ }^{56}$, regardless of harms to their personal advantage or top-down regulations. The pursuit of freedom was also considered as a foundation for the fullness of a human being. Freedom was associated with the possession of autonomy, both external and internal. They pointed out that the dignity and value of a man of science should settle on his internal autonomy, like a ship on a friendly shore, finding its fullest expression in his intellectual freedom, honesty and righteousness. Their manifestation should be: independence in the creative process and independence of all non-scientific determinants that can paralyze his will, i.e. authorities (scientific, religious, or political ones) or social and economic conditions.

Our humanity cannot be realized without it. As Tadeusz Czeżowski emphasized in his reflections on the category of freedom: "The wisdom of life [...] has already shown us that someone who only considered in his behavior his

eds. Joanna Dudek, Tomasz Turowski, Paweł Walczak, Joanna Zegzuła-Nowak (Zielona Góra: Oficyna Wydawnicza of University of Zielona Góra, 2018), 165-180.

${ }^{55}$ Dylus, 42.

${ }^{56}$ Izydora Dąmbska, “Gdy myślę o słowie »wolność«," Znak 1981, no. 7 (325): 859. 
physical abilities, would soon fall into the slavery of his own desires, which finally - against himself - would lead him to a disaster. A wise man [...] controls his passions and is guided in proceedings not by desire, but by what is right and thus achieves freedom from his original nature" ${ }^{57}$

Hence, philosophers from the Lvov-Warsaw School believed that also in science, as a sphere capturing the full scale of human mind, freedom is next to objective truth its axiological pillar. They emphasized that it should constantly accompany scholars in their creative drudgery, conditioning impartiality, selflessness and objectivity, constituting a remedy for phenomena degrading it, i.e. bias, dogmatism or mental narrowness.

Moreover, it is also an indispensable element of the attitude of scientific criticism, without which it is impossible to practice and develop science at all. Critical reflection, on the other hand, is a way to improve scientific theories, clean them of ideological foundations, giving an opportunity to strive for their most reliable justification.

They were also aware that freedom conditions the creative exchange of thoughts and the possibility of mutual cooperation between scholars. The achievements of science are often the result of their mutual inspirations. Intellectual independence promotes an atmosphere of understanding among people of science. Therefore, without their mutual cooperation, there wouldn't be many important scientific fruits, and humanity would face scientific stagnation and even regression. As T. Kotarbiński wrote: "A collective act needs a brave word, and at the same time requires some regulation of it. The word grows stronger as a factor of a collective action, but loses its full power if it does not feel completely free" ${ }^{58}$ Therefore, each scientific discussion must take place with the internal freedom of its participants, consisting in honesty of thinking, sincerity towards oneself, unlimited aspiration to explain matters considered, as well as not to refrain from pressure, not to accept insufficiently justified views, based only on authority, dogma or ideological premises. It should also be remembered that science is constantly evolving and one must be open to new solutions, explanations, taking into account previously unknown facts, and consequently

57 Tadeusz Czeżowski, "Paradoks wolności," in Tadeusz Czeżowski, Filozofia na rozdrożu (Analizy metodologiczne) (Warszawa: PWN, 1965), 143.

${ }^{58}$ Tadeusz Kotarbiński, "Wolność słowa w nauce," Trybuna Literacka 1.07.1957, no. 4, in Wallis, folder Rps 14, vol. 4: Rps 206. 
modifying one's views and even reorienting them. Thus, the scholar must be able to change his attitude without threatening disadvantageous consequences. As Mieczysław Wallis pointed out with emphasis: "There exist last words in science: there are no final words". Hence, "Nothing is more contrary to the spirit of science than to make dogmas a scientific statement". For a religious man, a doubt means a sin, for a scholar a critical approach to science is an obligation". ${ }^{59}$

Hence, as it was emphasized by another philosopher from the School circle, Kazimierz Ajdukiewicz, scholars should always have the freedom to choose research areas, to formulate scientific statements and to announce them. The framework of free creativity is primarily marked by such phenomena as: strong belief in the rightness of professed views and the possibility and need to act in accordance with them. It is also important that the scholar should always be ready to stand in their ruthless, uncompromising defense if necessary. The philosopher postulated as follows: "The freedom to practice science requires [...] that the practitioner enjoys the freedom of choice of issues, the freedom to choose the method, i.e. the way to solve the issues, freedom of thought and freedom of speech" ${ }^{60} \mathrm{He}$ also pointed out that the reservoir of resources that take away the voice of scholars could be extremely diverse, including the means of physical coercion and also those of a moral nature. Hence, one needs to be particularly sensitive to them, not to accept them, even unconsciously. Such actions can take not only blunt, but also subtle and sophisticated forms of pressure, from mockery, ridicule, intimidation, through blackmail, loss of good name and prestige, to "gratification" of submissive silence. As he wrote:

You can literally plug one's mouth, you cannot let him/her speak at a meeting, you can refuse to accept his/her speech for printing. However, you can also, without using any of these means of physical coercion, without gagging anyone's mouth or using preventive censorship, deter people from publishing what they would like to preach with the fear of repression, [...] fear of unpleasant consequences [...]. These unpleasant consequences do not have to consist of imprisonment, fines, deprivation of a job, etc. There can appear a negative opinion of the public, the whole society or a certain fraction we take into account" ${ }^{61}$

${ }^{59}$ Wallis, folder Rps 19, vol. 3-5:168.

${ }^{60}$ Kazimierz Ajdukiewicz, "O wolności nauki," in: Nie być w myśleniu posłusznym. Ossowscy, socjologia, filozofia, ed. Jakub Karpiński (Londyn: Polonia, 1989), 177.

${ }^{61}$ Ibidem, 178. 
When considering the approach of this scholar, however, it is worth looking at it with some criticism. Is Ajdukiewicz not a bit too radical in his views? Every scholar in his activities depends on many factors influencing him, both formal and material ones, determining, regulating as well as, limiting his scientific activities. $\mathrm{He}$ is also responsible for the results of his work before superiors and financial decision makers. Therefore, the choice of research issues and the form of presentation of scientific results usually require their inclusion in well-defined, sometimes top-down forms. The researcher in his methodology must also follow certain procedures necessary to carry out the undertaken research tasks. However, usually it does not harm his intellectual freedom but rather determines the scope of scientific work and organizes his activities. Therefore, it does not have to pose a threat to his internal autonomy.

Tadeusz Kotarbiński also expressed concern for the autonomy in science, appealing in one of his interviews as follows:

science must be autonomous, and not governed by top-down regulations. One cannot direct the science by ordering the choice of problems and methods, one cannot define the results in science or demand that observations would be in accordance with the generalizations adopted before the study. [...] Let's take care $[\ldots]$ of the most of freedom. ${ }^{62}$

He also emphasized that on the basis of science, education and upbringing, internal autonomy and freedom of conscience of a scholar should always go in accordance with respect for human dignity. Hence, he urged:

On the way blocked by hardships and requiring an organized action, leading to just social rules, one cannot miss everything that is required by the personal dignity of each individual person. I would like to emphasize this postulate among many others. The right to be guided by one's own conscience, the right to express one's true beliefs, the right to have respect from fellow citizens, not excluding state authority. ${ }^{63}$

${ }^{62}$ Tadeusz Kotarbiński, "Wyjąć konserwę z puszki. Profesor Tadeusz Kotarbiński o drogach rozwoju polskiej nauki,” Po prostu. Tygodnik studentów i młodej inteligencji 1957, no. 4 (419): 1-2, in: Wallis, folder Rps 14, vol. 4: 202.

${ }^{63}$ Tadeusz Kotarbiński, “O wychowaniu nowego człowieka mówią łódzcy naukowcy,” Dziennik tódzki 9.05.1948, no. 127 (1033): 7. 
In turn, Stanisław Ossowski warned against a serious threat to the freedom of science, which is its ideologization - subordination not to the service of objective truth, but to the orders of intellectual or political elites. Hence, he appealed to scholars to keep steadfastness of their character and tenacity in sticking to their scientific views. He wrote about the role of a scholar:

A researcher is a man whose professional duties include a lack of obedience in thinking. This is his social service not to obey anything in carrying out his professional activities. In this regard, he must not obey either the synod or the committee, nor the minister, nor the emperor, nor God. If he is obedient, if he changes his views on orders, or if his thought is not in accordance with his words, he misses his duties. ${ }^{64}$

Maria Ossowska, on the other hand, drew attention to the social dimension of scientific activity. She argued that freedom, most fully manifested in an attitude of civil courage, is one of the prime values constituting the social order, "in which there are no oppressors and the oppressed, privileged or handicapped, [...] in which everyone can develop their possibilities in an atmosphere of freedom" ${ }^{6}{ }^{5}$ Only in such conditions, which oppose intellectual slavery, is it possible to reach the real possibilities and abilities of the scholar and use them in the service of the whole society.

Hence, there is a constant and unquestionable need to preach with emphasis, as an important scientific postulate - much deeper than just a methodological, is freedom of thought and speech. The freedom of science is an expression of its independence from all those factors that threaten or devaluate it, destroying its foundations and goals that should guide it.

Therefore, philosophers from the School of Kazimierz Twardowski indicate that despite the changing times and circumstances of practicing science, freedom is one of the indispensable conditions for doing it, ensuring the possibility of progress in the field of knowledge, cultural and social development.

\footnotetext{
${ }^{64}$ Stanisław Ossowski, “Taktyka i kultura,” in Nie być w myśleniu posłusznym, 5.

${ }^{65}$ Maria Ossowska, Wzór demokraty. Cnoty i wartości (Lublin: Daimonion, 1992), 14-15.
} 
Conclusion: An intellectual message for the contemporaneity from the Lvov-Warsaw School

Philosophers from the Lvov-Warsaw School, laying the foundations for the constitution and development of modern methodology and theory of science, pointed out that science without axiological framework was impossible and groundless. The sense of scientific work is expressed in the way of thinking and acting, which is conducive not only to the cognitive taming of the world, but also to the realization of the values underlying our humanity. Particularly important for them turned out to be those that allowed them to build intellectual identity both their own and the entire Polish nation. In promoting philosophical culture and pointing out permanent axiological foundations, they placed hopes for awakening patriotism and a sense of national community in the society, which despite changing circumstances and times, constituted an uncompromising important way to keep, strengthen, develop and maintain the continuity of native culture and national identity. Hence, they constantly expressed, "the conviction that the scholar's mission obliges him to implement certain moral norms or loyalty to certain values" 66 .

Consequently, these philosophers left behind an important intellectual message - that values do exist and should apply in science, constantly illuminating the activities of scientists and determining their mutual obligations, as well as in the sphere of collective life. This directive should also be obligatory in contemporary world. That even nowadays, in the world of rapid progress of science one could legitimately speak of the socially important role of scientists. That they would enjoy the universal recognition and trust which they deserve. That through their contribution to the native culture, they would maintain the spirit of national unity. That their voice would be important and appreciated in contemporary public discourse, determing truly valuable paths, in favour of universal harmony and well-being of collective life.

Therefore, scientific work is a work for universal values. Hence, every scholar bears a special responsibility for the views expressed and knowledge transferred, not only to himself, his superiors, a scientific collective but above all to the whole society.

\footnotetext{
${ }^{66}$ Dylus, 5.
} 
Although the activity of Kazimierz Twardowski's School expired decades ago, its work showing science as axiologically oriented human activity with the power of integrating human collectivities, has not lost its validity, finding many followers today.

Its directives in the field of ethics of science have proved to be timeless in many assumptions, especially the main thesis about the presence of values in the world of science, gaining more and more recognition in the modern world. This position was already proclaimed in the 1980s, among others by Jan Woleński, a leading researcher of the Lvov-Warsaw School, arguing strongly that science has its internal axiology. He claimed that: "Science can be considered in the context of values in several ways". ${ }^{67}$ The purpose of science can be values of various kinds: not only epistemological but also technological, connected with civilization or economy. More importantly, according to the philosopher, science also has its ethical dimension because "there is a certain ethos associated with science, say »external« - $[\text { where }]^{68}$ the freedom of scientific research can be understood precisely as an element of this external ethos" ${ }^{69}$ Like the representatives of the Lvov-Warsaw School, he postulated that the scholar should be responsible for the results of his work, be honest, truthful, impartial, not to succumb to external influences and pressures and not to pay attention to his own benefits. What is more, he claimed that aesthetic values might also be present in science. Scientific activity may be subject to aesthetic evaluation or provide experience of this type.

This thesis can be found in the statements of many contemporary philosophers, methodologists and scientists. One of them is Adam Świeżyński, who says that:

Modern science, as a special kind of human activity, constitutes an important part of global culture. Theories and scientific models are laboratory equivalents of works of art collected in galleries and museums that can be viewed, admired, criticized. Science and its findings, like artistic activities, can arouse various emotions among its creators and recipients. ${ }^{70}$

${ }^{67}$ Jan Woleński, "Nauka i wartości," in Człowiek i świat wartości, ed. Józef Lipiec (Kraków: Krajowa Agencja Wydawnicza, 1982), 164.

${ }^{68}$ Personal note.

${ }^{69}$ Ibidem.

${ }^{70}$ Świeżyński, 442. 
Hence, nowadays there is no longer any doubt that "Science is [...] inevitably entangled in values. As Adam Grobler rightly points out, this raises another important question: "which science is better, that is, what values science should pursue?". ${ }^{71}$ What is more, the thesis is also gaining an importance that in scientific activity, as in other spheres of specifically human activity, we are dealing with valuation (issuing judgments on values) and that it has a significant impact on the creative process itself and its methodology. As A. Lekka-Kowalik argues: "Science researchers [...] admit that, de facto, scientists formulate valuations and these valuations influence what methods are used and which theories are considered to be the best ones, etc." ${ }^{\prime 2}$ This approach to practicing science is undoubtedly an intellectual heritage of creative activity of scholars from the LvovWarsaw School.

\section{Bibliography}

Ajdukiewicz, Kazimierz. "O wolności nauki." In Nie być w myśleniu posłusznym. Ossowscy, socjologia, filozofia, ed. Jakub Karpiński, 177-191. Londyn: Polonia, 1989.

Czeżowski, Tadeusz. "Uniwersytet Nowoczesny. Przegląd zadań i zasad organizacyjnych." In: Tożsamość uniwersytetu. Antologia tekstów profesorów Uniwersytetu Mikołaja Kopernika, 13-27, ed. Włodzimierz Więcławski. Toruń: Oficyna Drukarska Wojewódzkiej Biblioteki Publicznej i Książnicy Miejskiej im. Mikołaja Kopernika w Toruniu, 1994.

Czeżowski, Tadeusz. "Kazimierz Twardowski jako nauczyciel." In Kazimierz Twardowski. Nauczyciel - Uczony - Obywatel, 7-12. Lwów: PTF 1938.

${ }^{71}$ Adam Grobler, "Nauka i kultura: o potrzebie humanistycznej filozofii przyrody," in Panorama współczesnej filozofii polskiej. Księga pamiątkowa VIII Polskiego Zjazdu Filozoficznego, ed. Jacek Juliusz Jadacki (Warszawa: Semper, 2010), 252.

${ }^{72}$ Lekka-Kowalik, 8. In the twentieth-century Polish philosophy, this issue was considered in an original way also by Henryk Elzenberg. Interestingly, however, he resolved this issue negatively, considering that there was no place for valuation in science According to him, there is evident dissonance between scientific thinking and evaluation. In science, we are dealing with perceptive-sensual (or perceptive-introspective) judgments, while evaluative thinking (appropriate for culture-forming activity) is based on intuitive cognition. He even argued that valuation can have harmful consequences for science, posing a threat to impartiality, criticism, objectivity and the pursuit of truth. Henryk Elzenberg, „Nauka i barbarzyństwo,” in Wartość i człowiek. Rozprawy z humanistyki i filozofii (Toruń: UMK, 2004), 241. 
Czeżowski, Tadeusz. "Wkład Kazimierza Twardowskiego do teorii nauki." Ruch Filozoficzny 1959, vol. XIX, no: 1-2: 4-9.

Czeżowski, Tadeusz. "Paradoks wolności." In Tadeusz Czeżowski, Filozofia na rozdrożu (Analizy metodologiczne), 141-150. Warszawa: PWN, 1965.

Dąmbska, Izydora. “Czterdzieści lat filozofii we Lwowie 1898-1938.” Przegląd Filozoficzny 1948, no. 1-3: 14-25.

Dąmbska, Izydora. „Gdy myślę o słowie »wolność«.” Znak 1981, no. 7 (325): 855-860.

Dylus, Aniela. Problematyka etyki nauki u przedstawicieli szkoły lwowsko-warszawskiej. Warszawa: Akademia Teologii Katolickiej, 1987.

Elzenberg, Henryk. "Nauka i barbarzyństwo." In Henryk Elzenberg, Wartość i człowiek. Rozprawy z humanistyki i filozofii, 232-246. Toruń: UMK, 2004.

Friszke, Andrze. Anatomia buntu. Kuroń. Modzelewski i komandosi. Kraków: Znak, 2010.

Fritzhand, Marek. "Dyskusja nad referatami prof. dr. T. Czeżowskiego i dr. H. Jankowskiego.” Etyka 1967, no. 2: 131-139.

Grobler, Adam (wypowiedź). "Nauka i kultura: o potrzebie humanistycznej filozofii przyrody.” In Panorama współczesnej filozofii polskiej. Księga pamiątkowa VIII Polskiego Zjazdu Filozoficznego, 239-264, ed. Jacek Juliusz Jadacki, Warszawa: Semper, 2010.

Historia nauki polskiej, 1863-1918, T. IV, Cz. III, ed. Zofia Skubała-Tokarska. Wrocław, Warszawa, Kraków, Gdańsk, Łódź: PAN, 1987.

Ingarden, Roman. “Główne kierunki polskiej filozofii.” Studia Filozoficzne 1973, no. 1: 3-15.

Jacek Juliusz Jadacki. „W dziewięćdziesiątą rocznicę urodzin Kazimierza Ajdukiewicza.” Ruch Filozoficzny 1981, no. 1: 1-7.

Jadacki, Jacek Juliusz. "The Lvov-Warsaw School and its influence upon the Polish philosophy of the twentieth century." In The Significance of the Lvov-Warsaw School in European Culture, ed. Anna Brożek, 78-87. Wien: Springer, 2017.

Jadczak, Ryszard. "Kazimierz Twardowski o nauce i jej funkcjach." Zagadnienia Naukoznawstwa 4, no. 104 (1990): 623-631.

Jadczak, Ryszard. Powstanie filozofii analitycznej w Polsce. Noty Bibliograficzne. Toruń: Adam Marszałek, 1995.

Jadczak, Ryszard. “Z dziejów spotkania szkoły lwowsko-warszawskiej z marksizmem.” Edukacja Filozoficzna 1991, vol. 11: 99-107.

Kotarbiński, Tadeusz. "Kilka słów o walorach nauki." In Tadeusz Kotarbiński, Wybór pism, T. II. Myśli o Myśleniu, 337-341.Warszawa: PWN, 1958.

Kotarbiński, Tadeusz. Myśli o ludziach i ludzkich sprawach. Wrocław, Warszawa, Kraków, Gdańsk: PAN, 1986.

Kotarbiński, Tadeusz. “O wychowaniu nowego człowieka mówią łódzcy naukowcy.” Dziennik Łódzki 9.05.1948, no. 127 (1033): 1-12, http://bc.wbp.lodz.pl/dlibra/publication?id=59144\&tab=3 Access: 20.09.2019.

Kotarbiński, Tadeusz. “Upragnione fantazmaty.” In Tadeusz Kotarbiński, Pisma etyczne, 429430. Wrocław, Warszawa, Kraków, Gdańsk, Łódź: Zakład Narodowy im. Ossolińskich, 1987. 
Pobrane z czasopisma http://kulturaiwartosci.journals.umcs.pl

Kotarbiński, Tadeusz. "Wolność słowa w nauce." Trybuna Literacka 1.07.1957, no. 4. In: Mieczysław Wallis, Materiały Archiwalne. Warszawa: Archiwum Połączonych Bibliotek WFiS UW, IFiS PAN oraz PTF, folder Rps 14, vol. 4: 172-256.

Kotarbiński, Tadeusz. "Wyjąć konserwę z puszki. Profesor Tadeusz Kotarbiński o drogach rozwoju polskiej nauki." Po prostu. Tygodnik studentów i młodej inteligencji 1957, no. 4 (419): 1-2. In Mieczysław Wallis, Materiały Archiwalne. Warszawa: Archiwum Połączonych Bibliotek WFiS UW, IFiS PAN oraz PTF, folder Rps 14, vol. 4: 172-256.

Kuliniak, Radosław, Mariusz Pandura, Łukasz Ratajczak. Filozofia po ciemnej stronie mocy. Krucjaty marksistów i komunistów polskich przeciwko Lwowskiej Szkole Filozoficznej Kazimierza Twardowskiego. Część pierwsza: lata 1945-1951. Kęty: Marek Derewiecki, 2018.

Lekka-Kowalik, Agnieszka. Odkrywanie aksjologicznego wymiaru nauki. Lublin: KUL, 2008. Mackiewicz, Witold. Polska filozofia powojenna. Warszawa: Witmark, 2001.

Marciszewski, Witold. "Kwestia unaukowienia racjonalizmu przez logikę matematyczną a logistyczny antyirracjonalizm Szkoły Lwowsko-Warszawskiej." In Fenomen Szkoły Lwowsko-Warszawskiej, ed. Anna Brożek, Alicja Chylińska, 57-86. Lublin: Academicon, 2016.

Nowakowska, Wanda. Sylwetki łódzkich uczonych. Profesor Mieczysław Wallis. Łódź: Łódzkie Towarzystwo Naukowe, 2001.

Ossowska, Maria. "Fizyka współczesna a postawy moralne." In Maria Ossowska, O człowieku, moralności i nauce. Miscellanea, 453-463. Warszawa: PWN, 1983.

Ossowska, Maria. "Konferencja w Oksfordzie w sprawie obrony wolności akademickiej." In Maria Ossowska. O człowieku, moralności i nauce. Miscellanea, 290-292. Warszawa: PWN, 1983.

Ossowska, Maria. “Moralność: postęp czy regres." In Maria Ossowska, O człowieku, moralności i nauce. Miscellanea, 523-527. Warszawa: PWN, 1983.

Ossowska, Maria. Wzór demokraty. Cnoty i wartości. Lublin: Daimonion, 1992.

Ossowski, Stanisław. "Taktyka i kultura." In Nie być w myśleniu posłusznym. Ossowscy, socjologia, filozofia, ed. Jakub Karpiński, 129-139. Londyn: Polonia, 1989.

Paczkowska-Łagowska, Elżbieta. Psychika $i$ poznanie. Epistemologia Kazimierza Twardowskiego. Warszawa: PWN, 1980.

Promieńska, Halina. Trwanie i zmiana wartości moralnych. Katowice: UŚ, 1991.

Simons, Peter. "Filozofia logiczna, antyirracjonalizm i równość płci. Trzy atuty Oświecenia lwowsko-warszawskiego." In Fenomen Szkoły Lwowsko-Warszawskiej; ed. Anna Brożek, Alicja Chylińska, 21-36. Lublin: Academicon, 2016.

Skoczyński, Jan, Jan Woleński. Historia filozofii polskiej. Kraków: WAM, 2010.

Śnieżyński, Adam. "Doświadczenie aksjologiczne w poznaniu naukowym." In Oblicza doświadczenia aksjologicznego. Studia i rozprawy, ed. Piotr Duchliński, Grzegorz Hołub, 441-463, Kraków: WAM, 2011.

Twardowski, Kazimierz. "Dlaczego wiedza jest potęgą." Ruch Filozoficzny 1976, no. 12: 25-33. 
Twardowski, Kazimierz. Mowy i rozprawy z okresu jego działalności w Towarzystwie Nauczycieli Szkół Wyższych, ed. Karol Zagajewski (Lwów: Towarzystwo Nauczycieli Szkół Wyższych, 1912). https://www.sbc.org.pl/dlibra/publication/37960/edition/35622/content (access: 11.01.2020).

Twardowski, Kazimierz. O dostojeństwie Uniwersytetu. Poznań: Uniwersytet Poznański, 1933.; http://www.wbc.poznan.pl/dlibra/doccontent?id=48428 (access: 20.09.2019).

Twardowski, Kazimierz. "O dostojeństwie Uniwersytetu. Wprowadzenie i przygotowanie do druku wykładu Twardowskiego," ed. Ryszard Jadczak. Zagadnienia Naukoznawstwa 26, z. 3 (1990): 371-381.

Twardowski, Kazimierz. Podstawy wiedzy ludzkiej: Odczyta wygłoszony w Bibliotece Polskiej ${ }_{W}$ Wiedniu, $\quad$ http://rcin.org.pl/dlibra/aresults?action=SearchAction\&QI=E373A6 B0B85B7B22732F18789DF6B156-1 Access: 16.09.2019.

Tyburski, Włodzimierz. “Etos uczonego w Szkole Lwowsko-Warszawskiej.” In Polska filozofia analityczna. W kręgu szkoły lwowsko-warszawskiej, ed. Włodzimierz Tyburski, Ryszard Wiśniewski, 129-144. Toruń: UMK, 1999.

Wallis, Mieczysław. Materiały Archiwalne. Warszawa: Archiwum Połączonych Bibliotek WFiS UW, IFiS PAN oraz PTF, folders Rps 19, vol. 3-5: 1-237; 21: 1-206.

Woleński, Jan. “Jak mówić o historii filozofii analitycznej?” In Fenomen Szkoły LwowskoWarszawskiej, ed. Anna Brożek, Alicja Chylińska, 35-56. Lublin: Academicon, 2016.

Woleński, Jan. Filozoficzna szkoła lwowsko-warszawska. Warszawa: PWN, 1985.

Woleński, Jan. "Nauka i wartości.” In Człowiek i świat wartości, ed. Józef Lipiec, 164-168. Kraków: Krajowa Agencja Wydawnicza, 1982.

Woleński, Jan. Szkoła Lwowsko-Warszawska w polemikach. Warszawa: Wydawnictwo Naukowe Scholar, 1997.

Zegzuła-Nowak, Joanna. Polemiki filozoficzne Henryka Elzenberga ze szkołą lwowskowarszawską. Kraków: Scriptum, 2017.

Zegzuła-Nowak, Joanna. "Wzorzec człowieka nauki w założeniach programowych i postawach naukowych Marii i Stanisława Ossowskich.” In W kręgu twórczości Marii Ossowskiej: analiza - inspiracje - alternatywy, ed. Joanna Dudek, Tomasz Turowski, Paweł Walczak, Joanna Zegzuła-Nowak, 165-180. Zielona Góra: Oficyna Wydawnicza Uniwersytetu Zielonogórskiego, 2018. 


\title{
Streszczenie
}

Prawda i wolność jako aksjologiczne fundamenty uprawiania nauki w szkole lwowsko-warszawskiej

Artykuł prezentuje wkład reprezentantów szkoły lwowsko-warszawskiej dotyczący określenia aksjologicznego wymiaru nauki. W krzewieniu kultury filozoficznej oraz wskazywaniu trwałych fundamentów aksjologicznych pokładali oni nadzieje na rozbudzenie w społeczeństwie patriotyzmu oraz poczucia wspólnoty narodowej. Twierdzili też, że jeśli nauka ma służyć ludzkości, to nie może rozwijać się w sposób nieograniczony i niekontrolowany. Stąd obok określenia dyrektyw merytoryczno-metodologicznych, ważne było dla nich także określenie aksjologicznych ram uprawiania nauki, które miałyby strzec jej przed czynnikami ją deprecjonującymi i wyznaczać dlań słuszne cele. Nie mieli zatem wątpliwości, że w nauce powinny urzeczywistniać się wartości.

W nauce o mocnych i jasno określonych fundamentach aksjologicznych upatrywali oni zatem, nie tylko drogi zmierzającej do poprawy życia ludzkiego, ale także wewnętrznego rozwoju człowieka. Misją uczonego zatem powinna być wierność określonym wartościom, przede wszystkim prawdzie i wolności, nadającym działalności naukowej status doniosłej i zarazem autonomicznej sfery aktywności ludzkiej.

Słowa kluczowe: wartości, aksjologiczny wymiar nauki, szkoła lwowsko-warszawska, prawda i wolność w nauce

\section{Zusammenfassung}

\author{
Wahrheit und Freiheit als axiologische Fundamente \\ des Betreibens von Wissenschaft in der Lemberg-Warschau-Schule
}

Der Artikel stellt den Beitrag der Vertreter der Lemberg-Warschau-Schule zur Bestimmung der axiologischen Dimension der Wissenschaft dar. In der Verbreitung philosophischer Kultur und im Hinweisen auf beständige axiologische Fundamente hegten sie Hoffnungen, Patriotismus und Gefühl der Nationalgemeinschaft zu wecken. Sie behaupteten auch, dass sich die Wissenschaft nicht auf eine unbeschränkte und unkontrollierte Art entwickeln darf, sollte sie der Menschheit dienen. Neben der Bestimmung des meritorischmethodologischen Rahmens war es daher für sie wichtig, den axiologischen Rahmen für das Betreiben der Wissenschaft festzulegen. Sie hatten keine Zweifel, dass sich in der Wissenschaft Werte verwirklichen sollten. In der Wissenschaft mit starken und klar bestimmten axiologischen Fundamenten erblickten sie folglich einen Weg, der nicht allein zur Verbesserung des menschlichen Lebens, sondern auch zur inneren Entwicklung des Menschen 
führte. Die Sendung eines Wissenschaftlers soll daher auf der Treue gegenüber bestimmten Werten beruhen, vor allem gegenüber der Wahrheit und Freiheit, die der wissenschaftlichen Tätigkeit den Status eines bedeutsamen und zugleich autonomen Bereichs der menschlichen Tätigkeit verleiht.

Schlüsselworte: Werte, axiologische Dimension der Wissenschaft, Lemberg-WarschauSchule, Wahrheit und Freiheit in der Wissenschaft

Informacja o Autorze:

JOANNA ZEGZUŁA-NOWAK, doktor filozofii, adiunkt, Instytut Filozofii Uniwersytetu Zielonogórskiego; adres do korespondencji: al. Wojska Polskiego 71A, 65-762 Zielona Góra; e-mail: J.Zegzula-Nowak@ifil.uz.zgora.pl 